\title{
A Study of Structure, Thermal and Mechanical Properties of Free Machining Al-Zn-Sn-Bi Alloys Rapidly Solidified from Molten State
}

\author{
Nermin Ali Abdelhakim*, Rizk Mostafa Shalaby, Mustafa Kamal \\ Metal Physics Laboratory, Physics Department, Faculty of Science, Mansoura University, Mansoura, Egypt \\ Email: *drnerminsayed@yahoo.com,rizk2002@mans.edu.eg, kamal42200274@yahoo.com
}

How to cite this paper: Abdelhakim, N.A., Shalaby, R.M. and Kamal, M. (2018) A Study of Structure, Thermal and Mechanical Properties of Free Machining Al-Zn-Sn-Bi Alloys Rapidly Solidified from Molten State. World Journal of Engineering and Technology, 6, 637-650.

https://doi.org/10.4236/wjet.2018.63040

Received: June 1, 2018

Accepted: July 29, 2018

Published: August 1, 2018

Copyright $\odot 2018$ by authors and Scientific Research Publishing Inc. This work is licensed under the Creative Commons Attribution International License (CC BY 4.0).

http://creativecommons.org/licenses/by/4.0/

cC) (i) Open Access

\begin{abstract}
The objective of our study is to investigate the effect of rapid solidification technology using melt spun process from melt on environmentally free machining Al-0.1Zn alloys with tin-bismuth as free machining constituents. The main purpose of rapid solidification from melt is to have a high strength and thermal stability. Structural and thermal properties have been investigated by $\mathrm{x}$-ray diffraction (XRD), scanning electron microscope (SEM) and differential scanning calorimetry (DSC) techniques. Tensile test machine is used to study the mechanical properties such as ultimate tensile strength, elastic constants, yield strength and critical shear stress for free machining alloys. We find the best free machining aluminum alloy that has excellent machinability qualities is $\mathrm{Al}-0.1 \mathrm{Zn}-0.5 \mathrm{Sn}-0.54 \mathrm{Bi}$ melt spun alloy because it offers excellent mechanical properties. The highest values of tensile strength (431.5 MPa), yield strength $(393.9 \mathrm{MPa})$, fracture strength $(431.6 \mathrm{Mpa})$, toughness $\left(15.8 \times 10^{6}\right.$ $\mathrm{J} / \mathrm{m}^{3}$ ) generated from Al-0.1Zn-0.5Sn-0.54Bi alloy to meet the needs of free machining aluminum alloy applications.
\end{abstract}

\section{Keywords}

Free Machining Aluminum Alloys, Structural Analysis, Mechanical Behavior, Microhardness, Micro Indentation Creep

\section{Introduction}

Free machining aluminum alloys are well known in the art. These alloys typically include free machining compounds such as lead, tin, indium and bismuth or a combination of these elements for enhancing the machinability. More attention is paid to tin-bismuth system, since the levels of tin and indium have high prices, 
lead to unattractive free machining aluminum alloys economically. Selection of suitable cutting tool grade and machining parameters depends initially on a number of work piece material parameters, such as microstructure and the chemical composition [1]. Variations in microstructure can have a large effect on machinability [2]. The influences of composition on machinability are often complicated by the combined effects of the alloying elements and micro constituents consisting the work piece alloy. Free machining aluminum alloys are well known in literature [2] [3]. These alloys typically include free machining constituents that are insoluble but nonabrasive and soft and they are useful, helping in chip breakage and tool life [2]. More specifically, at the point of contact between the material and the tool, softening and melting occur. Therefore, breakage takes place, chips are formed and material removal is enhanced. It is well known that chip breaking is enhanced by the addition of $\mathrm{Pb}$ [2] [3] [4] to conventional aluminum alloys, since $\mathrm{Pb}$ has a poor solubility in solid aluminum and forms a soft, low melting point phase. Traditional lead free aluminum alloys form long continuous strips or curls, which are totally unacceptable. Over the last years, attention has been paid to eliminate $\mathrm{Pb}$ and $\mathrm{Pb}$ containing products due to their toxicity. New lead free aluminum alloys with good free cutting machinability have been recently developed [5] [6] [7]. While the Bartges et al. patent provides improvements in free machining alloys by limiting the levels of lead and bismuth, the presence of tin adversely affects the alloys mechanical properties, particularly impact properties. In other words, adding tin only makes this alloy brittle and renders it unacceptable where impact properties in a particular application may be important. Another drawback associated with free machining alloys containing tin only is a lack of corrosion resistance in environments, where hot brake fluid is present. Brake system components made from tin containing free machining alloys exhibit excessive corrosion in the presence of brake fluid [8]. In addition, the addition of tin is believed to contribute to artificial ageing response and bismuth does not have any deleterious effects on the mechanical properties of alloys [9] [10]. However, the addition of tin decreases both the critical temperature for tearing and the hot deformation resistance of a billet during extrusion, and these properties become more critical by increasing the amount of tin [9].

This paper aims to enhance the machinability of Al- $\mathrm{Zn}$ alloys with small traces from tin and bismuth as free machining constituents.

\section{Experimental Procedures}

\subsection{Materials and Sample Preparation}

Four free machining aluminum alloys of composition $\mathrm{Al}_{99.9-\mathrm{x}}-\mathrm{Zn}_{0.1}-\mathrm{Sn}_{\mathrm{X1}}-\mathrm{Bi}_{\mathrm{x} 2}$ where $\mathrm{X}_{1}=0.2 \%, 0.5 \%, 1 \%, 1.5 \%$ and $\mathrm{X}_{2}=0.22 \%, 0.54 \%, 1.08 \%, 1.63 \%$ were prepared from pure $\mathrm{Al}, \mathrm{Zn}, \mathrm{Sn}$ and $\mathrm{Bi}$ (purity > 99.99\%) using melt-spinning technique [11]. The alloys in the ceramic crucible are melted in an electric furnace at $660^{\circ} \mathrm{C}$ for 30 minutes. After heating for 30 minutes, the alloys become in 
a molten state and then shoot the rotating copper wheel which possesses a linear speed of $31.4 \mathrm{~m} / \mathrm{s}$. The resulting aluminum alloys have long ribbons about $65 \mu \mathrm{m}$ in thickness and $4 \mathrm{~mm}$ width.

\subsection{Sample Characterization}

Different techniques were used to investigate the structural properties of the melt spun ribbons including x-ray diffraction using $\mathrm{Cu} \mathrm{Ka}$ radiation at room temperature. The microstructure analysis was carried out on a scanning electron microscope (SEM) of type (JEOL JSM-6510LV, Japan) operate at $30 \mathrm{KV}$ with high resolution $3 \mathrm{~nm}$. The melting temperature of these alloys was determined by differential scanning calorimetry with a heating rate $10 \mathrm{~K} / \mathrm{min}$.

\subsection{Sample Characterization}

Different techniques were used to investigate the structural properties of the melt spun ribbons including $\mathrm{x}$-ray diffraction using $\mathrm{Cu} \mathrm{Ka}$ radiation at room temperature. The thermal properties of free machining Al-0.1Zn-Sn-Bi alloys studied by differential scanning calorimeter, with a heating rate $10 \mathrm{~K} / \mathrm{min}$ [12]. Scanning electron microscope (SEM) operate at $30 \mathrm{KV}$ with high resolution 3 $\mathrm{nm}$ was used to study the microstructure analysis.

\subsection{Mechanical Measurements}

\subsubsection{Tensile Test Machine}

The tensile test machine is showed in Figure 1. The specimen is fitted in the laws of the testing machine and subjected to a tensile load. The applied load (stress) and the resulting elongation (strain) of the specimen are measured computerized. The process is repeated with increased load until the specimen breaks. Using these data a stress-strain diagram is plotted using computer set up contains software program to find out tensile properties.

\subsubsection{Microhardness}

The standard technique used for measuring the hardness of metals is Vickers hardness test. Vickers hardness is a measure of the hardness of a material, calculated from the size of an impression produced under load by a pyramid-shaped diamond indenter [13].

\section{Result and Discussion}

\subsection{Structure}

Metal alloys prepared using rapid solidification from melt was reported by Pol Duwez et al. [12]. The X-ray diffraction (XRD) patterns of the melt-spun $\mathrm{Al}-\mathrm{Zn}$-Sn-Bi ribbons rapidly solidified from melt at $\left(700^{\circ} \mathrm{C}\right)$. X-ray diffraction patterns of $\mathrm{Al}-\mathrm{Zn}-\mathrm{Sn}-\mathrm{Bi}$ alloys as indicated in Figure 2 show presence of two phases of the structure face centered cubic $\alpha$-Al and intermetallic compounds $\mathrm{Al}_{0.403} \mathrm{Zn}_{0.597}$ of alloys. The details of the XRD analysis are shown in Table 1 . By using Scherer Formula [14]: 


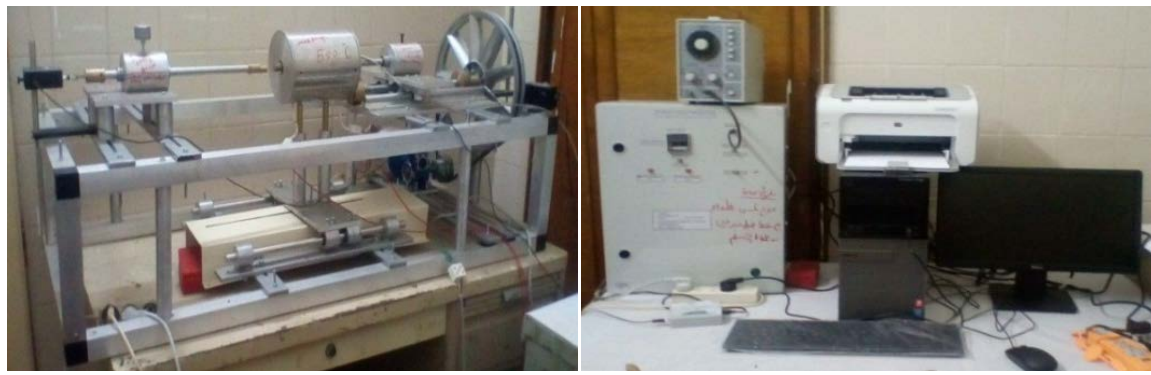

Figure 1. Photographic view of tensile test machine.
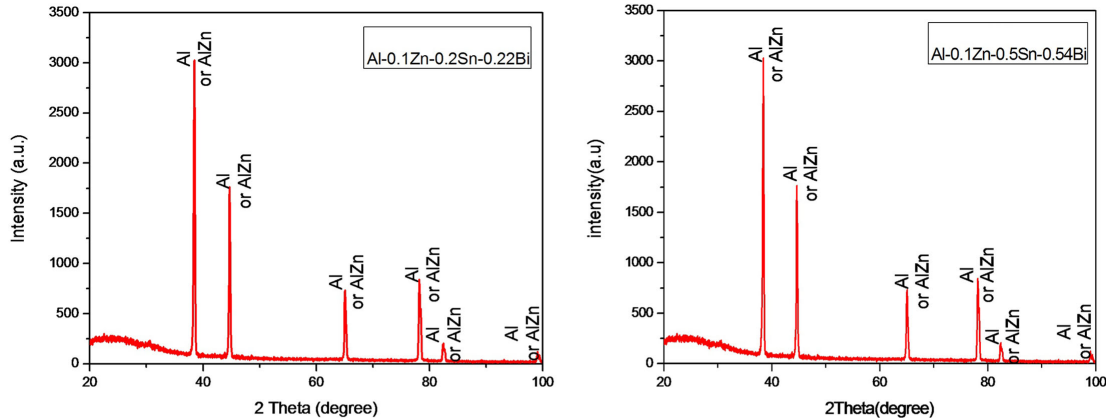

(a)

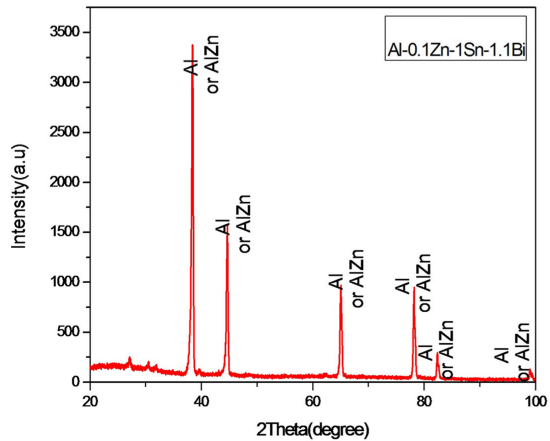

(c)

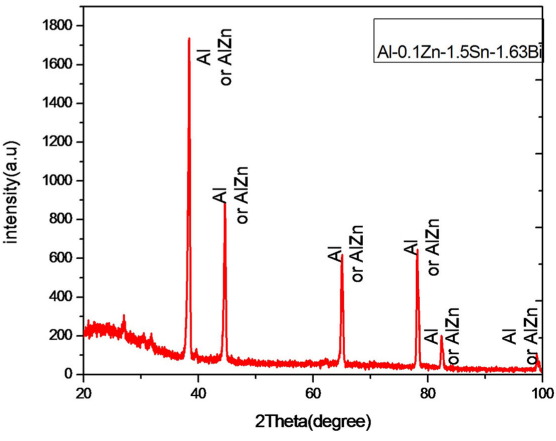

(d)

Figure 2. The XRD patterns of free machining Al-Zn-Sn-Bi alloys.

Table 1. The details of the XRD analysis of free machining aluminum alloys.

\begin{tabular}{|c|c|c|c|c|}
\hline Alloy & Phases & Crystal system & $\begin{array}{c}\text { Lattice parameter }(\mathrm{a}) \\
\text { of } A l \text { phase }(\AA)\end{array}$ & $\begin{array}{c}\text { Particle } \\
\text { size }(n m)\end{array}$ \\
\hline $\mathrm{Al}-0.1 \% \mathrm{Zn}-0.2 \% \mathrm{Sn}-0.22 \% \mathrm{Bi}$ & $\mathrm{Al}, \mathrm{AlZn}$ & FCC, Anorthic & 4.051 & 343.1 \\
\hline Al-0.1\%Zn-0.5\%Sn-0.54\%Bi & $\mathrm{Al}, \mathrm{AlZn}$ & FCC, Anorthic & 4.055 & 330.6 \\
\hline Al-0.1\%Zn-1\%Sn-1.08\%Bi & $\mathrm{Al}, \mathrm{AlZn}$ & FCC, Anorthic & 4.052 & 317.9 \\
\hline $\mathrm{Al}-0.1 \% \mathrm{Zn}-1.5 \% \mathrm{Sn}-1.63 \% \mathrm{Bi}$ & $\mathrm{Al}, \mathrm{AlZn}$ & FCC, Anorthic & 4.055 & 320.5 \\
\hline
\end{tabular}

where: $B$ is the broadening of diffraction line measured at half its maximum intensity (radians), $t$ is the diameter of crystal particle, $\theta_{B}$ is the Bragg angle and $\lambda$ is the wavelength of $\mathrm{x}$-ray. From $\mathrm{x}$-ray analysis, adding $\mathrm{Sn}-\mathrm{Bi}$ to Al-0.1wt\% $\mathrm{Zn}$ alloy produced a change in its matrix microstructure (particle size, lattice para- 
meters and lattice distortion) and the shape of formed phases such as peak intensity, peak broadness and peak position. A cubic crystal gives diffraction lines whose $\sin ^{2} \theta$ values satisfy the following equation obtained by combining the Bragg law with the plane-spacing equation for the cubic system:

$$
\frac{\sin ^{2} \theta}{h^{2}+k+l^{2}}=\frac{\lambda^{2}}{4 a^{2}}
$$

In Table 1 the lattice parameter a calculated from the $\sin ^{2} \theta$ value for the highest-angle line, it was found approximately the same value $(a=4.054 \AA)$. It is also indicated that the number of atoms/unit cell is the same approximately (3.8 atoms/unit cell).

\subsection{Microstructure Analysis}

The microstructures of $\mathrm{Al}-\mathrm{Zn}-\mathrm{Sn}-\mathrm{Bi}$ alloys are shown in Figure 3. As shown in Figure 3(a), the microstructure of free machining aluminum alloy Al-Zn-Sn-Bi is irregular grains. When the content of tin-Bismuth increases, the microstructure becomes finer as shown in Figures 3(b)-(d) and its distribution becomes more homogeneous and this greatly improved it's mechanical properties.

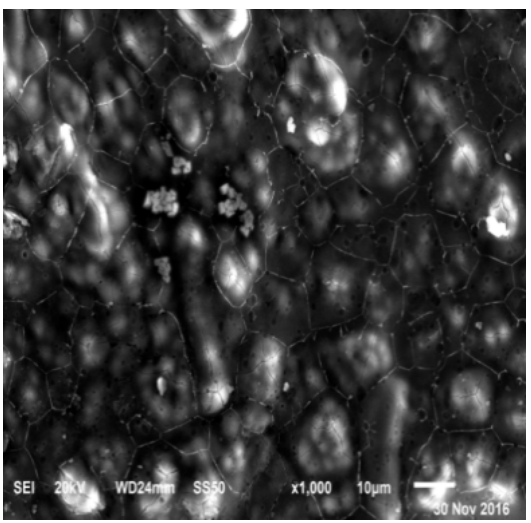

(a)

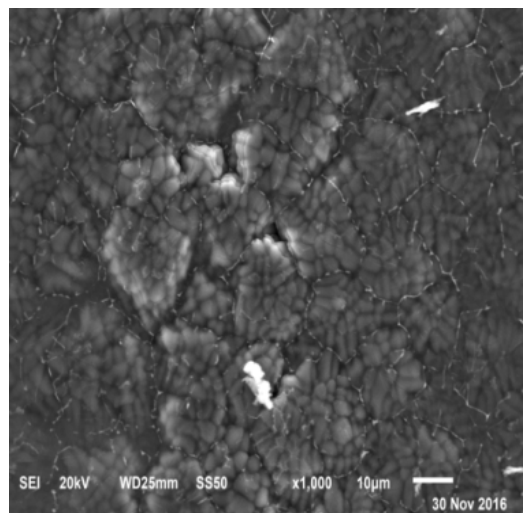

(c)

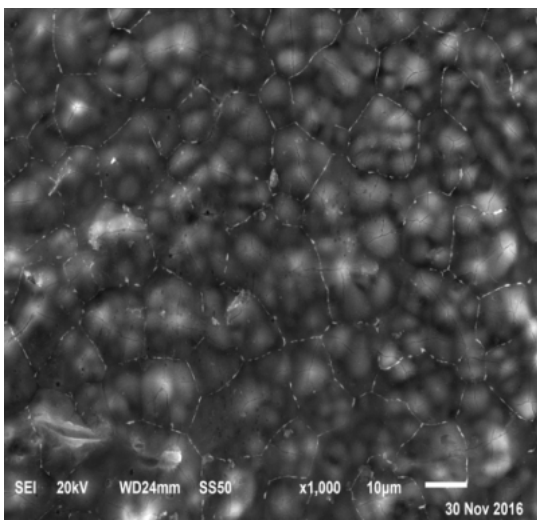

(b)

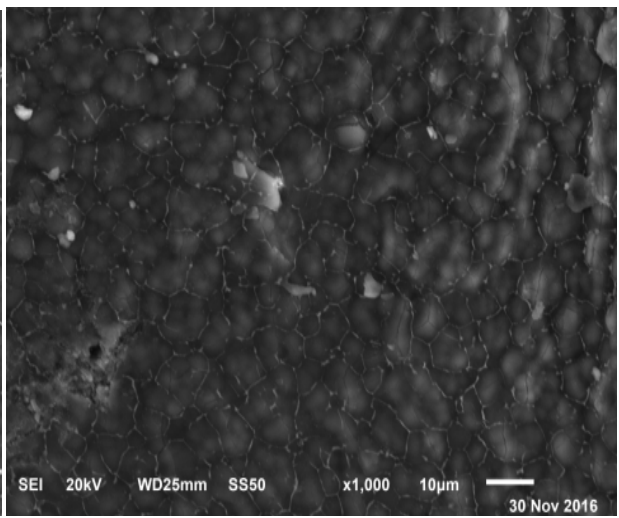

(d)

Figure 3. SEM micrograph of free machining Al-Zn-Sn-Bi alloy. (a) Al-0.1wt\% $\mathrm{Zn}-0.2 \mathrm{wt} \% \mathrm{Sn}-0.22 \mathrm{wt} \% \mathrm{Bi}$; (b) Al-0.1wt\% Zn-0.5wt\% Sn-0.54wt\% Bi; (c) Al-0.1wt\% $\mathrm{Zn}-1 \mathrm{wt} \% \mathrm{Sn}-1.08 \mathrm{wt} \% \mathrm{Bi}$; (d) Al-0.1wt\% Zn-1.5wt\% Sn-1.63wt\% Bi. 


\subsection{Thermal Properties}

The DTA curves obtained for the four Al-Zn-Sn-Bi alloys during heating with heating rate $10 \mathrm{~K} / \mathrm{min}$ are shown in Figure 4 . Figure 4 shows a single endothermic peak corresponding to the melting reaction. From this figure the melting point $\left(T_{m}\right)$, solidus temperature $\left(T_{s}\right)$, liquidus temperature $\left(T_{l}\right)$ and enthalpy of fusion $\left(H_{f}\right)$ of these alloys were calculated and presented in Table 2. The melting point decreases continuously with tin-bismuth content due to presence of higher concentration of intermetallic compound and increasing its concentration. The enthalpy of fusion is higher at Al-0.1 Zn-0.5 Sn-0.54 Bi alloy due to presence of intermetallic compound. The enthalpy $\Delta \mathrm{H}$, Specific heat $C_{p}$ and other thermal parameters of Al-Zn-Sn-Bi alloy varied. From Figure 4, the melting point of $\mathrm{Al}-\mathrm{Zn}-\mathrm{Sn}-\mathrm{Bi}$ alloys is nearly the same which indicate the thermal stability of the free machining $\mathrm{Al}-\mathrm{Zn}-\mathrm{Sn}-\mathrm{Bi}$ alloys.

\subsection{Thermal Diffusivity and Internal Friction}

Internal friction and thermal diffusivity of $\mathrm{Al}-\mathrm{Zn}-\mathrm{Sn}-\mathrm{Bi}$ was studied via utilizing dynamic resonance technique. The internal friction $Q^{-1}$ values which calculated from resonance peak shows in Figure 5. Internal friction measurement is one of sensitive ways that are suitable to examine microstructural changes and defect motion such as atomic diffusion, dislocation activity and grain boundary sliding. The free vibration is determined by the decay of measurement in amplitude of vibrations during free vibration. The internal friction can be calculated by [13]:

Table 2. Thermal analysis of free machining aluminum alloys.

\begin{tabular}{ccccccc}
\hline Alloy & $T_{m}(\mathrm{~K})$ & $T_{s}(\mathrm{~K})$ & $T_{L}(\mathrm{~K})$ & $\begin{array}{c}\text { Ethalpy } \\
(\mathrm{j} / \mathrm{g})\end{array}$ & $\begin{array}{c}\text { Specific heat } \\
C_{p}(\mathrm{j} / \mathrm{kg} \cdot \mathrm{k})\end{array}$ & $\begin{array}{c}\text { Entropy change } \\
(\mathrm{j} / \mathrm{g} \cdot \mathrm{k})\end{array}$ \\
\hline Al-0.1\%Zn-0.2\%Sn-0.22\%Bi & 933.43 & 927.10 & 942.97 & 117.6 & 7410.2 & 125.79 \\
Al-0.1\%Zn-0.5\%Sn-0.54\%Bi & 932.76 & 925.90 & 946.84 & 197.0 & 9407.8 & 210.43 \\
Al-0.1\%Zn-1\%Sn-1.08\%Bi & 931.09 & 921.84 & 941.51 & 159.1 & 8088.4 & 170.8 \\
Al-0.1\%Zn-1.5\%Sn-1.63\%Bi & 928.47 & 918.39 & 944.14 & 142.5 & 5533.98 & 153.05
\end{tabular}

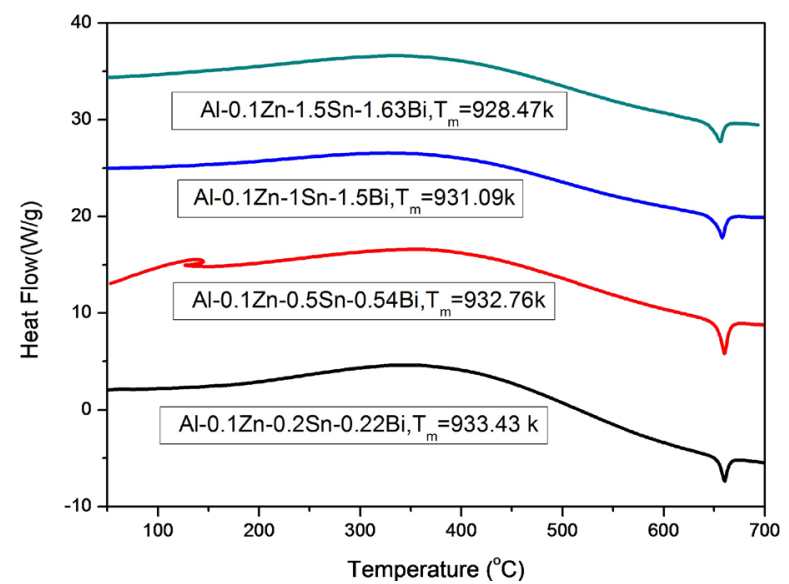

Figure 4. Endothermic curves of free machining aluminum alloys. 


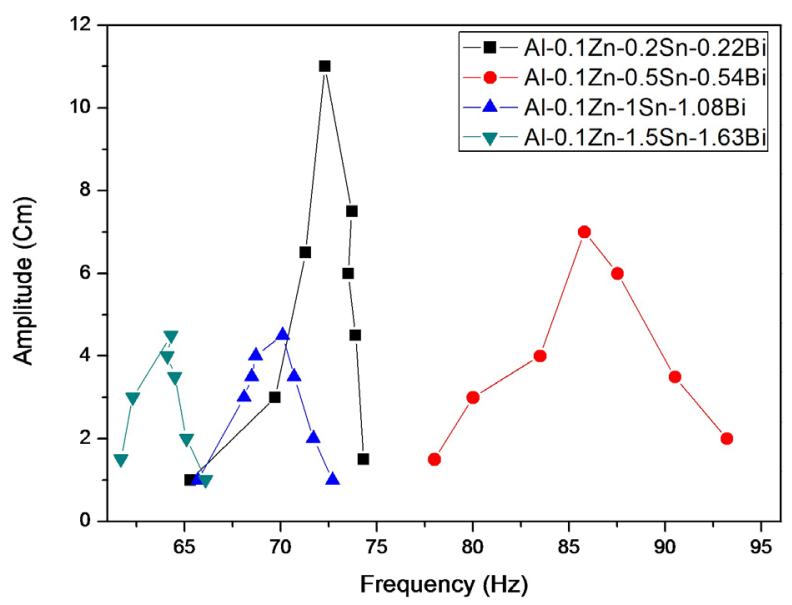

Figure 5. Resonance curves of free machining aluminum alloys.

$$
Q^{-1}=\frac{1}{\sqrt{3}} \frac{\Delta f}{f}
$$

The time rate of temperature change determines the values thermal diffusivity of any a material when heat via through material as showed in Table 3. Thermal diffusivity can be calculated by [15] [16].

$$
D_{t h}=\frac{2 t^{2} f_{0}}{\pi}
$$

where $f_{0}$ is resonance frequency and $\mathrm{t}$ is the thickness of the melt-spun ribbon. From Table 4, it is observed that the thermal diffusivity of Al-0.1Zn-0.5Sn-0.54Bi is higher than other Al-Zn-Sn-Bi alloys, so the thermal diffusivity in this case is a function of Bi content or the composition. Different values of thermal diffusivity of all Al-Zn-Sn-Bi alloys are caused by rapid solidification process. So this technique could improve a heat transport in the materials and improve thermal diffusivity. From Table 4, the internal friction for all Al-Zn-Sn-Bi alloys are very small. A low level of $Q^{-1}$ for free machining Al-Zn-Sn-Bi alloys, implies a rigid structure which may be due to absence or to the locking of crystal defects.

\subsection{Mechanical Measurements}

\subsubsection{Elastic Moduli and Tensile Properties}

The tensile test machine is most frequently performed to determine mechanical properties. Information on various tensile properties like proportional limit, elastic limit, yield point, yield strength, ultimate strength, fracture strength, toughness and modulus of elasticity is given in our article. Using tensile test machine for drawing stress-strain characteristic curve as shown in Figure 6 to calculate tensile strength, yield strength and elastic moduli and then listed in Table 3. The alloys after increasing tin and bismuth to $0.5 \mathrm{wt} \% \mathrm{Sn}-0.54 \mathrm{wt} \% \mathrm{Bi}$ transform from elastic-plastic behavior to plastic behavior as showed in Figures 5(b)-(d). The critical shear stress (the minimum shear stress required to begin plastic deformation or slip) which is acting on the slip plane at which the lattice 
Table 3. Experimental values of elastic moduli and tensile properties of free machining aluminium alloys.

\begin{tabular}{|c|c|c|c|c|c|c|c|c|}
\hline Alloy & $\begin{array}{c}\text { Tensile } \\
\text { strength } \\
(\mathrm{MPa})\end{array}$ & $\begin{array}{c}\text { Yield } \\
\text { strength } \\
(\mathrm{MPa})\end{array}$ & $\begin{array}{c}\text { Fracture } \\
\text { Strength } \\
(\mathrm{MPa})\end{array}$ & $\begin{array}{l}\text { Toughness } \\
\left(\mathrm{J} / \mathrm{m}^{3}\right) \times 10^{6}\end{array}$ & $\begin{array}{l}\text { CSS } \\
(\mathrm{GPa})\end{array}$ & $\begin{array}{c}E \\
\text { (Gpa) }\end{array}$ & $\begin{array}{c}G \\
(\mathrm{Gpa})\end{array}$ & $\begin{array}{c}B \\
\text { (Gpa) }\end{array}$ \\
\hline $\mathrm{Al}-0.1 \% \mathrm{Zn}-0.2 \% \mathrm{Sn}-0.22 \% \mathrm{Bi}$ & 154.6 & 178.3 & 167.2 & 2.83 & 9.2 & 43.6 & 16.1 & 49.2 \\
\hline $\mathrm{Al}-0.1 \% \mathrm{Zn}-0.5 \% \mathrm{Sn}-0.54 \% \mathrm{Bi}$ & 431.5 & 393.9 & 431.6 & 15.80 & 9.7 & 107.2 & 39.6 & 129.4 \\
\hline $\mathrm{Al}-0.1 \% \mathrm{Zn}-1 \% \mathrm{Sn}-1.08 \% \mathrm{Bi}$ & 315.5 & 274.3 & 315.6 & 2.98 & 15 & 116.6 & 43.0 & 134.6 \\
\hline $\mathrm{Al}-0.1 \% \mathrm{Zn}-1.5 \% \mathrm{Sn}-1.63 \% \mathrm{Bi}$ & 284.4 & 255.4 & 283.7 & 4.39 & 9.3 & 67.1 & 24.8 & 75.5 \\
\hline
\end{tabular}

Table 4. Internal friction and thermal diffusivity of free machining aluminium alloys.

\begin{tabular}{ccc}
\hline Alloy & $Q^{-1}$ & $D_{t h}\left(\mathrm{~m}^{2} \cdot \mathrm{sec}^{-1}\right) \times 10^{-7}$ \\
\hline Al-0.1\%Zn-0.2\%Sn-0.22\%Bi & 0.011 & 6.6 \\
Al-0.1\%Zn-0.5\%Sn-0.54\%Bi & 0.035 & 7.0 \\
Al-0.1\%Zn-1\%Sn-1.08\%Bi & 0.026 & 6.4 \\
Al-0.1\%Zn-1.5\%Sn-1.63\%Bi & 0.020 & 5.9 \\
\hline
\end{tabular}

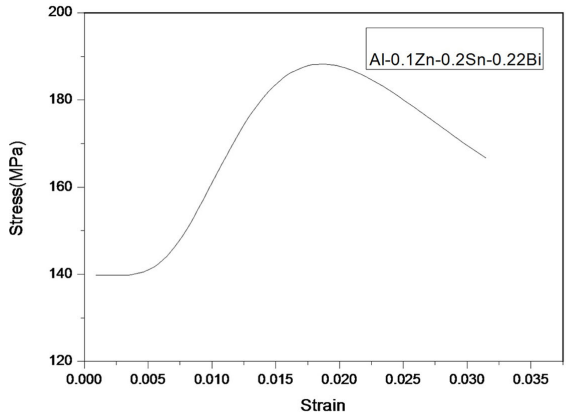

(a)

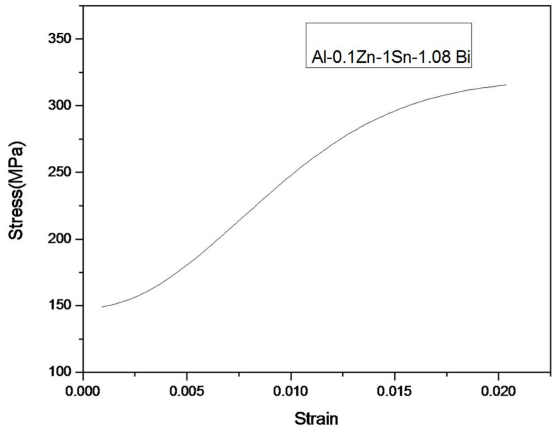

(c)
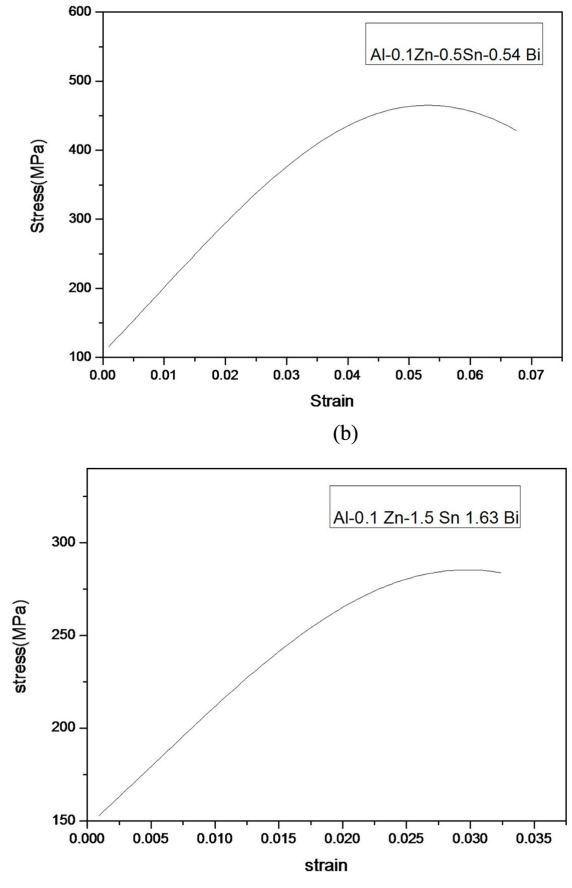

(d)

Figure 6. Stress-strain characteristic curves of free machining Al-Zn-Sn-Bi alloys.

becomes unstable. That is, the plastic deformation begins when the shear stress attains the value of the critical resolved shear stress as shown in Figure 6. It is cleared that a presence of large amount $\alpha-\mathrm{Al}$ rich phase in $\mathrm{Al}-0.1 \mathrm{Zn}-0.5 \mathrm{Sn}-0.54 \mathrm{Bi}$ causes the strengths resistant deformation increases. Consequently, the increase of resistant of deformation means the increase of strength. The elastic constants of the metallic alloys which were fundamental physical properties especially for 
the mechanical properties such as strength, plastic deformation and fracture were reported previously using single crystals [17]. From Table 3, the free machining Al-0.1Zn-0.5Sn-0.54Bi and Al-0.1Zn-1Sn-1.08 alloys have higher values of Young's modulus, shear modulus, bulk modulus and critical shear stress. The highest values of tensile strength (431.5 MPa), yield strength (393.9 MPa), fracture strength $(431.6 \mathrm{Mpa})$, toughness $\left(15.8 \times 10^{6} \mathrm{~J} / \mathrm{m}^{3}\right)$ generated from Al-0.1Zn-0.5Sn-0.54Bi alloy to meet the needs of free machining aluminum alloy applications.

\subsubsection{Debye Temperature}

Having computed the elastic moduli, one can calculate the Debye temperature, which is an important fundamental parameter closely related to many physical properties such as elastic stiffness, specific heat and melting temperature. The expression for the Debye temperature $\theta_{D}$ in terms of the sound velocities for an isotropic body is given by the following Equation (5) [18]. Values of the Debye temperature of Al-Zn-Sn-Bi alloys are shown in Table 5.

$$
\theta_{D}=\frac{h}{k_{B}}\left(\frac{3}{4 \pi V_{a}}\right)^{1 / 3} V_{m}
$$

where $h$ is the plank's constant, $k_{B}$ is the Boltzmann constant, $N_{A}$ is Avogadro's number, $V_{a}$ is the molar volume calculated from the effective molecular weight and density (i.e. $\frac{M}{\rho}$ ) and $V_{m}$ is the mean ultrasonic velocity defined by the relation

$$
V_{m}=\frac{1}{3}\left(\frac{1}{V_{l}^{3}}+\frac{2}{V_{t}^{3}}\right)^{-1 / 3}
$$

where $V_{t}$ and $V_{l}$ are the transverse and longitudinal wave velocities in the solid defined by the relations

$$
V_{t}=\sqrt{\frac{G}{\rho}} \text { and } V_{l}=\sqrt{\frac{3 B+4 G}{3 \rho}}
$$

where $B$ is bulk modulus and $G$ is the shear modulus.

\subsubsection{Spalling}

Spalling generally produces cracks normal to surface whenever the stresses arise from thermal contraction. Such cracking most commonly occurs in brittle materials as a result of thermal contractions. In certain cases either a phase transformation is an important causative factor. The spalling behavior of a material is related to several properties other than the thermal expansion coefficient, these properties include strength, modulus of elasticity, and thermal diffusivity [18]. It is convenient; to assign an index to spalling resistance of quenched ribbon, using the following equation

$$
\text { Spalling Resistance Index }(\mathrm{SRI})=\frac{D_{t h} T_{s}}{\alpha E}
$$


where $D_{t h}$ is the thermal diffusivity, $E$ is the young's modulus, $T_{s}$ is the tensile strength and $\alpha$ is the thermal expansion. Table 5 shows that the spalling resistance Index values are very small and negligible.

\subsubsection{Microhardness and Micro Creep}

The creep behavior of the free machining Al-Zn-Sn-Bi alloys is presented in Figure 7, where the indentation diagonal length is plotted against the indentation time applying a constant load of $10 \mathrm{gf}$. It is observed that by increasing loading time, the indentation length increased. Hardness values listed in Table 6. It is cleared that Values of hardness increased by increasing Sn-Bi concentration due to $\mathrm{Sn}$ and $\mathrm{Bi}$ precipitates in Al-matrix. Figure 8 shows the variation of Vickers hardness number versus indentation time for Al-Zn-Sn-Bi alloys. Figure 7 generally shows a slow decrease in hardness with time. Figure 7 noted that the hardness of Al-Zn-Sn-Bi alloys at starting point $5 \mathrm{sec}$ gradually increases with increasing tin and bismuth content reaches its maximum value of $418.4 \mathrm{MPa}$ for Al-0.1Zn-1.5Sn-1.63Bi. The stress exponent can be obtained by the following equation and listed in Table 3 according to [19] and [20]:

$$
n=\left[\frac{\partial \ln \dot{d}}{\partial \ln H_{v}}\right]_{d}
$$

This equation is used to determine the mechanisms of deformation, where the type of mechanism is determined by the value of the stress exponent, where $d$ is the length of indentation diagonal, $H_{V}$ is the number of Vickers hardness and $\dot{d}$ is the rate of variation in the diagonal length of indentation. A straight line would be obtained by plotting $\dot{d}$ against $H_{V}$ on double logarithmic scale as shown in Figure 9, whose slope gives the stress exponent [21]. The values of stress exponent used to determine the mechanisms controlling the deformation process. The $n$ values around 1 are related to diffusion creep, $n$ values close to 2 related to grain boundary sliding and mechanisms attributed to dislocation movement such as slip creep are related to $n$ values in the range of 5 - 7 which moves up to higher values than 8 when particles reinforcement take place [22]. The grain boundary sliding mechanism is shown in Al-0.1Zn-Sn-Bi alloys.

\section{Indentation creep Resistance}

Figure 10 plots the strain and indentation time relationships of $\mathrm{Al}-\mathrm{Zn}-\mathrm{Sn}-\mathrm{Bi}$ alloys. We obtain typical indentation creep curve, as shown in Figure 10. The first stage records a fast increase of strain with time of the indentation starts from beginning up to $10 \mathrm{~s}$ of indentation time. The second stage represents a slow increase region in which the strain increases by lower rates for all alloys. In general, Al-0.1Zn-0.2Sn-0.22Bi alloy have lower creep resistance.

\section{Conclusion}

The addition of tin and bismuth as a free machining constituent to Al-0.1Zn rapidly solidified alloy lead to the formation of the intermetallic compounds $\mathrm{Al}_{0.403} \mathrm{Zn}_{0.597}$, finally dispersed in the $\mathrm{Al}$ matrix. With the content of tin and 
Table 5. Debye temperature and spalling resistance of free machining alloy.

\begin{tabular}{ccc}
\hline Alloy & $\theta_{D}(\mathrm{k})$ & $\begin{array}{c}\mathrm{SRI}\left(\mathrm{m} \cdot \mathrm{k} \cdot \mathrm{sec}^{-2}\right) \\
\times 10^{-6}\end{array}$ \\
\hline Al-0.1\%Zn-0.2\%Sn-0.22\%Bi & 456.8 & 1.05 \\
Al-0.1\%Zn-0.5\%Sn-0.54\%Bi & 785.9 & 9.30 \\
Al-0.1\%Zn-1\%Sn-1.08\%Bi & 1202.8 & 3.98 \\
Al-0.1\%Zn-1.5\%Sn-1.63\%Bi & 813.8 & 4.20 \\
\hline
\end{tabular}

Table 6. Hardness and stress exponent value of free machining alloy.

\begin{tabular}{ccc}
\hline Alloy & $H_{V}(\mathrm{MPa})$ & $n$ \\
\hline Al-0.1wt\% Zn-0.2wt\% Sn-0.22wt\% Bi & 303.06 & 1.92 \\
Al-0.1wt\% Zn-0.5wt\% Sn-0.54wt\% Bi & 320.85 & 2.43 \\
Al-0.1wt\% Zn-1wt\% Sn-1.08wt\% Bi & 343.83 & 3.10 \\
Al-0.1wt\% Zn-1.5wt\% Sn-1.63wt\% Bi & 418.41 & 4.23 \\
\hline
\end{tabular}

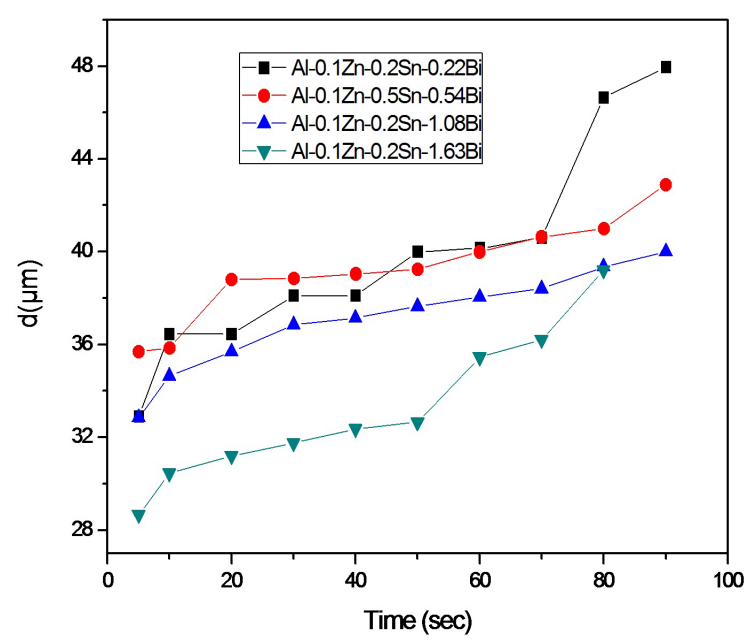

Figure 7. Variation of indentation length with loading time.

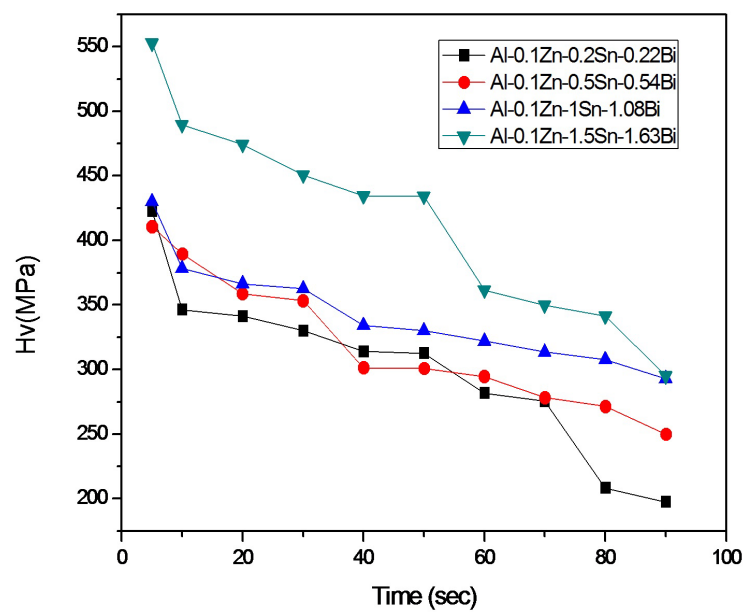

Figure 8. Variation of hardness with indentation time. 

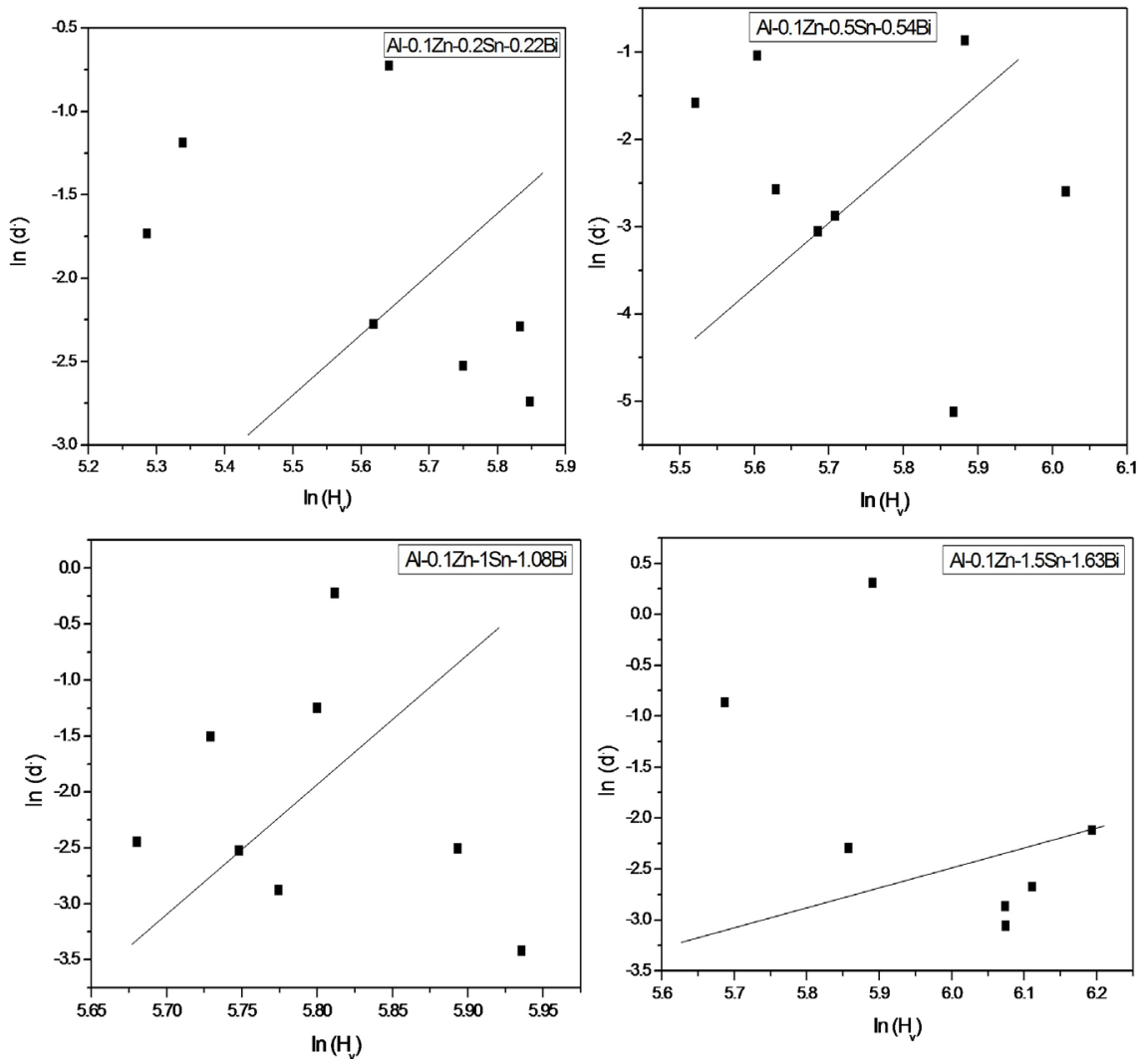

Figure 9. In-ln plot of the Vickers hardness numbers against the dwell time of indentationat load $25 \mathrm{gf}$ for free machining alloys.

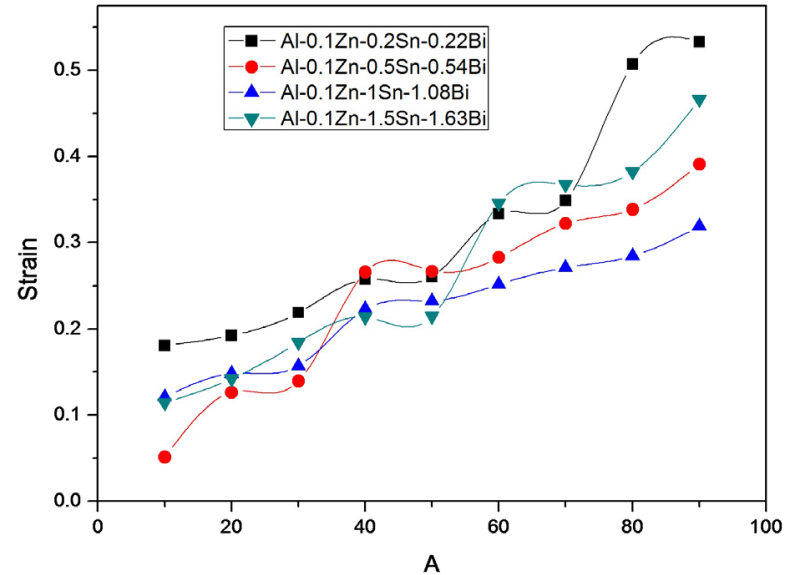

Figure 10. The creep behavior of free machining aluminum alloys.

bismuth increasing more, the microstructure becomes finer and its distribution becomes more homogeneous. The finer and more homogeneous microstructure leads to suitable effect on the mechanical properties of free machining aluminum alloys. The highest values of tensile strength (431.5 MPa), yield strength (393.9 MPa), fracture strength $(431.6 \mathrm{Mpa})$, toughness $\left(15.8 \times 106 \mathrm{~J} / \mathrm{m}^{3}\right)$ generated from $\mathrm{Al}-0.1 \mathrm{Zn}-0.5 \mathrm{Sn}-0.54 \mathrm{Bi}$ alloy to meet the needs of free machining aluminum alloy applications. The melting point of $\mathrm{Al}-\mathrm{Zn}-\mathrm{Sn}-\mathrm{Bi}$ alloys is nearly the 
same which indicates the thermal stability of the free machining $\mathrm{Al}-\mathrm{Zn}-\mathrm{Sn}-\mathrm{Bi}$ alloys. The thermal diffusivity of Al-0.1Zn-0.5Sn-0.54Bi is higher than other $\mathrm{Al}-\mathrm{Zn}$-Sn-Bi alloys. The internal friction for all $\mathrm{Al}-\mathrm{Zn}-\mathrm{Sn}-\mathrm{Bi}$ alloys is very small and this implies a rigid structure which may be due to absence or to the lacking of crystal defects.

\section{Conflicts of Interest}

The authors declare no conflicts of interest regarding the publication of this paper.

\section{References}

[1] Timelli, G. and Bonollo, F. (1971) Influence of Tin and Bismuth on Machinability of Lead Free 6000 Series Aluminium Alloys. Material Science and Technology, 27, 299.

[2] Davis, J.R. (1989) Machining of Aluminum and Aluminum Alloys. ASM International, 16, 761-804.

[3] Bray, J.W. (1989) Aluminum Mill and Engineered Wrought Products. In: Rooy, E.L., Ed., Materials Park, OH, ASM International, Vol. 2, 17-483.

[4] Wouters, O. and Hosson, J.Th.M. (2003) Lead Induced Inter Granular Fracture in Aluminum Alloy AA6262. Material Science and Engineering A, A361, 331-337. https://doi.org/10.1016/S0921-5093(03)00521-5

[5] Sircar, S. (2002) Free Machining Aluminum Alloy Containing Bismuth or Bismuth-Tin for Free Machining and a Method of Use. Reynolds Metals Company, Richmond, VA, USA, US Patent No. 6409966.

[6] Sircar, S. (2001) Free-Machining Aluminum Alloy and Method of Use. Reynolds Metals Company, Richmond, VA, USA, US Patent No. 6315947.

[7] Bartges, C.W. and Klemp, T.J. (2004) Lead-Free 6XXX Aluminum Alloy. Alcoa Cent., PA, USA, European Patent No. 1464717.

[8] Bartges, C.W., Klemp, T.J., Scott, G.D. and Allyn, A.J. (1996) Substantially Lead-Free 6xxx Aluminum Alloy. Aluminum Company American, Pittsburgh, Pa., Patent No. $5,522,950$.

[9] Røyset, J., Sæter, J.A., Ustad, T. and Reiso, O. (2002) Effects of Sn Addition on Microstructure, Extrudability, Mechanical Properties and Machinability of a $6082 \mathrm{Al}-$ loy. Material Science Forum, 396-402, 1205-1210. https://doi.org/10.4028/www.scientific.net/MSF.396-402.1205

[10] Koch, S. and Antrekowitsch, H. (2008) Free-Cutting Aluminium Alloys with Tin as Substitution for Lead. BHM, 153, 278-281. https://doi.org/10.1007/s00501-008-0390-5

[11] Kamal, M., Pieri, J.C. and Jouty, R. (1983) Les Mémoires scientifiques de la Revue de métallurgie, 143-148.

[12] Shalaby, R.M., Kamal, M. and Waqlan, A.S. (2016) Influence of Rapid Solidification and Lithium Additions on Microstructure and Mechanical Properties of Aluminum Based Alloys. Journal of Advances in Physics, 12, 4440-4450.

[13] Shalaby, R.M., Abdelhakim, N.A. and Kamal, M. (2017) Effect of Rapid Solidification on Mechanical Properties of Free Machining Lead Free Aluminum Alloys for Improved Machinability. Journal of Advances in Physics, 13, 5155-5166.

[14] Cullity, B.D. (1978) Elements of X-Ray Diffraction, Addison-Wesely, Reading, Vol. 
2, 248.

[15] Roebben, G., Bollen, B., Brebels, A., Humbeeck, J.V. and Biest, O.V. (1997) Impulse Excitation Apparatus to Measure Resonant Frequencies, Elastic Moduli, and Internal Friction at Room and High Temperature. Review of Scientific Instruments, 68, 4511-4515. https://doi.org/10.1063/1.1148422

[16] Gilman, J.J. (1975) Mechanical Behavior of Metallic Glasses. Journal of Applied Physics, 46, 1625-1633. https://doi.org/10.1063/1.321764

[17] Nakamura, M. and Kimura, K. (1991) Elastic Constants of $\mathrm{TiAl}_{3}$ and $\mathrm{ZrAl}_{3}$ Single Crystals. Journal of Material Science, 26, 2208-2214. https://doi.org/10.1007/BF00549190

[18] Kamal, M., Badr, S. and Abdelhakim, N.A. (2014) An Analysis of the Structural and Physical Stability of Quenched Ribbons Pb-Sn-Sb-Ca Alloys for Electrowinning. International Journal of Engineering and Technology, 14, 119-129.

[19] Juhász, A., Tasnádi, P. and Kovács, I. (1986) Superplastic Indentation Creep of Lead-Tin Eutectic. Journal of Material Science Letters, 5, 35-36.

https://doi.org/10.1007/BF01671427

[20] Mahmudi, R., Geranmayeh, A.R., Mahmoodi, S.R. and Khalatbari, A. (2007) Room-Temperature Indentation Creep of Lead-Free Sn-Bi Solder Alloys. Physica Status Solidi (A) Applications and Materials, 204, 2302-2308.

https://doi.org/10.1002/pssa.200622583

[21] Roumina, R., Raeisinia, B. and Mahmudi, R. (2004) Room Temperature Indentation Creep of Cast Pb-Sb Alloys. Scripta Materiala, 51, 497-502.

https://doi.org/10.1016/j.scriptamat.2004.05.048

[22] Torre, A.D., Adeva, P. and Aballe, M. (1991) Indentation Creep of Lead and Lead-Copper Alloys. Journal of Material Science, 26, 4351-4354.

https://doi.org/10.1007/BF00543650 